\section{Živko Mikić \\ Filozofski fakultet Beograd}

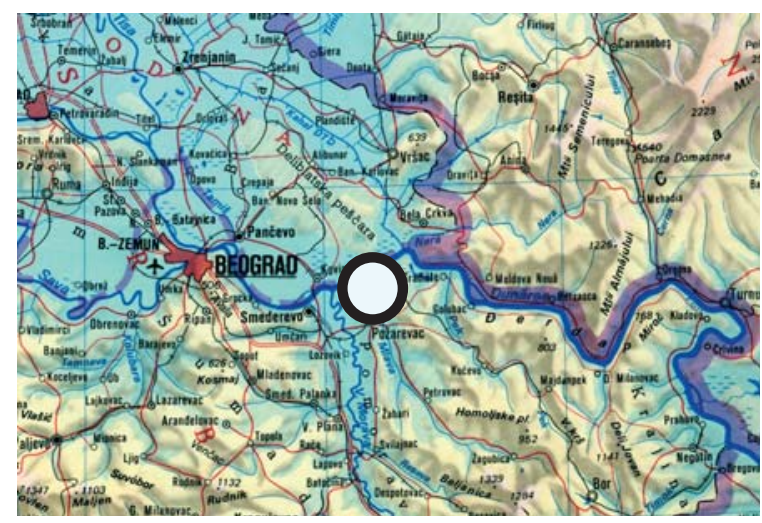

Viminacium, Stari Kostolac, Srbija

LAT 44" 44' 09" / LONG 21 12' 42"

\title{
TREPANACIJA LOBANJA NA ANTIČKOM VIMINACIJUMU - ANTROPOLOŠKE INFORMACIJE
}

\begin{abstract}
ABSTRAKT
Prilog obrađuje četiri lobanje muškog pola uzrasta izmedju 40 i 60 godina individualne starosti. Na njima su zapaženi tragovi patoloških promena, odnosno hirurških intervencija u regijama parietalnih $i$ okcipitalnih kostiju. Konkretno, na dve lobanje su tragovi trepanacije sasvim jasni (nekropola Više grobalja, broj 1037 i nekropola Pećine, broj 2570). Na lobanji broj 1651/b (nekropola Više grobalja) nalazimo tragove samo započete trepanacije, dok se na lobanji broj 2847 (nekropola Pećine) najverovatnije radi o jednoj atipičnoj obliteraciji u zoni suture coronalis.
\end{abstract}

KlJuČne reci: antropologida, nekropola Pećine, nekropola VišE grobalja, polna pripadnost, INDIVIDUALNA STAROST, TREPANACIJA LOBANJA, ISTORIJA MEDICINE.

\section{UVOD}

Antički Viminacijum je imao vrlo razvijeno lekarstvo, što bez sumnje potvrđuju nalazi metalnih medicinskih instrumenata i čak očuvane pastile iz groba jednog lekara'. Obrađujući humani osteološki materijal sa Viminacijuma počev od 1976. godine, autor je konstatovao vrlo veliki broj loše saniranih fraktura (Status post fracturam) naročito dugih kostiju postkranijalnog skeleta. Taj podatak bi mogao da ukaže, da je - recimo, lekara bilo malo prema broju stanovnika, tako da svako nije mogao da dobije njihove usluge koje su uz to mogle biti

1. Korać 1986 i skupe. Druga mogućnost je da su pojedinci na Viminacijum dolazili sa već stečenim povredama i to prvenstveno zbog svoje povećane profesionalne mobilnosti. Zato bi najverovatnije bilo pretpostaviti da su sve ove nabrojane mogućnosti oscilirale tokom intenzivnog života na Viminacijumu, te da su bile i u nekoj međusobnoj uslovljenosti.

$\mathrm{Na}$ Viminacijumu je do 1990. godine antropološki pregledano oko 11.000 grobnih sadržaja, odnosno još više individualnih skeleta. Sve poznate nekropole do sada arheološki iskopavane sa teritorije velikog Rimskog carstva nisu dale ni približan antropološki obim. Zbog toga se slobodno može reći da Viminacijum zapravo predstavlja danas jednu instituciju i u antropološkom smislu. 
Predmetne lobanje se izdvajaju od ostalog antropološkog fundusa po tragovima trepaniranja. Inače, trepanacija lobanja je najstarija hirurška intervencija na glavi/lobanji koja je ostavila i svoje materijalne tragove na humanom osteološkom materijalu. Najstariji tragovi takvih "hirurških zahvata" na moždanom delu glave, pa samim tim i lobanje, u Evropi postoje na subfosilnom materijalu (cca 12000 godina). Od početka mlađeg kamenog doba takve lobanje se učestalije javljaju, tako da su za pojedine delove Evrope izrađene i karte rasprostiranja ovog fenomena, uključujući i periode metalnog doba i pisane istorije. ${ }^{1}$ Međutim, sa teritorije Srbije lobanje sa tragovima trepanacije poznate su sa svega nekoliko nalazišta. Hronološki najstarije od njih su sa nekropole bronzanog doba u Mokrinu, ${ }^{2}$ u kojoj nalazimo čak nekoliko lobanja sa obnovljenom trepanacijom, što pokazuje da je procenat preživljavanja ove "najstarije neurohirurške operacije" bio vrlo visok. Potom sledi tzv. ilirska lobanja iz Krive Reke u zapadnoj Srbiji, na kojoj su obavljena tri trepanaciona zahvata. ${ }^{3}$

Kada se radi o periodima pisane istorije, sa naše teritorije lobanje sa tragovima trepanacije potiču sa Viminacijuma, koje će biti obrađene u ovom prilogu, zatim sa srednjovekovne nekropole u Gamzigradu i sa nekropole oko manastira Davidovice kod Priboja na Limu. ${ }^{4}$

1. Kàroly 1964

2. Farkas - Liptak 1971

3. Mikić 1981

4. Mikić 2000

\section{MATERIJAL I METOD}

Kako je u abstraktu sasvim kratko već pomenuto, predmet ovog priloga su četiri lobanje muškog pola u uzrastu između 40 i 60 godina života. Lobanje broj 1037 i 1651/b iskopane su na nekropoli Više grobalja, a lobanje broj 2570 i 2847 na nekropoli Pećine. ${ }^{5}$ Prilikom uobičajene antropološke obrade humanog osteološkog materijala do 1990. godine, ove lobanje su izdvojene na osnovu karakterističnih promena na kranijalnom delu. Prethodno su obrađene standardnom antropološkom metodologijom koju su koncipirali D. Ferembach (Pariz), I. Schwidetzky (Majnc) i M. Stloukal (Prag) 1979. godine, koju je prihvatilo 36 antropologa iz Evrope, Sjedinjenih država i Kanade, a među kojima je i autor priloga. Tom prilikom im je utvrđena polna pripadnost i individualna starost $\mathrm{u}$ trenutku smrti.

Pokazalo se da po svojim antropomorfološkim karakteristikama sasvim pouzdano sve lobanje mogu da se pripišu muškom polu. Međutim, individualna starost nije mogla sasvim precizno da im se odredi. Zbog nekompletne i slabe očuvanosti ona je određena okvirno. Tako se pokazalo da je muškarac iz groba broj 1037 (nekropola Više grobalja) u trenutku smrti bio star oko 40 godina. Grob broj 1651 (nekropola Više grobalja) je bio masovan i sadržavao je skeletne ostatke 15 individua (obeleženih slovima od A do O). Muškarac obeležen 1651/B bio je star oko 50 godina. Grob broj 2570 (nekropola Pećine) bio je dvojni. Predmetna lobanja je pripadala muškarcu koji je u trenutku smrti imao oko 45 godina. Druga lobanja takođe odgovara muškarcu u uzrastu oko 60 godina. Sa nekropole Pećine potiče i četvrta lobanja ovog priloga. Nosi broj 2847, a individualna starost joj se kreće oko 60 godina života. Zbog specifičnog defekta ova lobanja je snimljena i radiološki.

Sve lobanje su ilustrovane na tablama I, II, III i IV.

\footnotetext{
5. oba naziva su preuzeta iz savremene katastarske podele zemljišta
} 


\section{REZULTATI, DISKUSIJA I ZAKLJUČAK}

Sve nauke i naučne discipline koje se bave izučavanjem trepanacije lobanja (arheologija, antropologija, etnologija, medicina, istorija medicine, kao i prirodne nauke - fizika, hemija i biologija) se slažu da se pod ovim terminom podrazumeva probijanje koštanog omotača i intervencija na spoljnoj moždanoj opni. Međutim, razlozi za ovakvu intervenciju na lobanji, odnosno glavi živog čoveka (postmortalnim trepanacijama se u ovom prilogu nećemo baviti) su mnogostruki. Najčešće se pominju progresivne glavobolje ili razna povređivanja čija su posledica razni hematomi.

Sam termin "trepanacija" potiče iz mlađe etnomedicine i zapravo je neologizam iz elemenata starogrčkog (jonsko-atičkog) i francuskog jezika, a što znači - probušiti. Najstariji pomen ovog fenomena srećemo u Hipokratovim zapisima. U delu o glavi je dat detaljan opis, a kao najvažniji instrumenti se pominju metalni nož - strugač i nazubljena bušilica. Pre metalnih instrumenata nekoliko hiljada godina su korišćeni kameni instrumenti za ovu najstariju hiruršku intervenciju. ${ }^{6}$

Na tabli I je ilustrovana lobanja broj 1037 sa nekropole Više grobalja. Relativno dobro je očuvana, s tim što joj nedostaje veći deo zatiljačne zone, kao i temporalne, pogotovu sa leve strane. Donja vilica je najvećim delom dobro očuvana. Pripadajući postkranijalni skelet je fragmentovan, ali je na osnovu regresionih odnosa dugih kostiju izračunat telesni rast koji se kretao oko $176 \mathrm{~cm}$. $^{7}$ Prema ukupnim morfometrijskim karakteristikama može pouzdano da se opredeli u robustni mediteranski antropološki tip.

Trepanacioni otvor na ovoj lobanji je lociran na gornjem delu zatiljačne zone, tj. na levoj parietalnoj kosti, i to na delu povinuća prema okcipitalnoj kosti. Elipsoidnog je oblika dimenzija $3 \times 4 \mathrm{~cm}$, dok je površina celog defekta nešto veća (približno $5 \times 6 \mathrm{~cm}$ ). Nedostaje deo

6. Ullrich - Weickmann 1964

7. Breitinger 1938 moždanog pokrivača ispod samog trepanacionog otvora, tako da je i on sačuvan većim gornjim delom (videti mikrofotografije na istoj tabli). $\mathrm{Na}$ ivicama koštanog defekta koji širinom od oko 1 $\mathrm{cm}$ prati unaokolo trepanacioni otvor, vidni su novoformirani osteofiti. To pokazuje da je ovaj hirurški poduhvat izveden tokom života ove individue, što znači da je preživeo samo otvaranje lobanjskog svoda, ali da je u kraćem vremenskom periodu posle toga i preminuo. Uzrok smrti nije sasvim jasan, ali bi se moglo pretpostaviti da je postoperativna preventiva mogla presudno uticati na fatalni ishod. Treba dodati da stvaranje novih osteofita (osteoplastična reakcija) po rubovima trepanacionog otvora nije velika, tako da je vreme preživljavanja moglo trajati nekoliko meseci.

Posle ove konstatacije treba dodati da je na karakter i tip koštanog defekta na ovoj lobanji sa antičkog Viminacijuma obraćena posebna pažnja. Ona se odnosi na činjenicu da neke bolesti (kao npr. impresione frakture, osteomielitis, odnosno tuberkolozni i tumorozni procesi, osteoporoza lobanjskog svoda, jamaste atrofije i moždani tumori) mogu da ostave otvore na prvi pogled vrlo slične trepanacionim. ${ }^{8}$ Pošto je utvrđeno da se radi o tipičnoj trepanaciji prstenasto-elipsastog oblika otvora, odmah se postavilo pitanje kakvim medicinskim instrumentom je izvedena. S obzirom da je očigledna tehnika struganja određenog dela kosti lobanjskog pokrivača, znači da je korišćen grublji instrumenat $u$ odnosu na nazubljenu cevastu bušilicu. Konkretno, korišćen je metalni strugač kojim je dobijen asimetrični trepanacioni otvor dimenzija $3 \times 4 \mathrm{~cm}$, odnosno $5 \times 6 \mathrm{~cm}$ na gornjoj površini koštanog defekta. Ostali detalji ovog hirurškog zahvata, kao što su detaljan opis hirurškog instrumentarijuma, eventualna upotreba anestetika i antiseptika, ne mogu biti analizirani. Međutim, konstatujemo prisustvo trepanacije lobanja na antičkom Viminacijumu u prvom slučaju, uz napomenu da ona nije bila direktan uzrok smrti ove individue, s tim što je period preživljavanja bio dosta kratak.

8. Schröder 1957 
Na tabli II je prikazana lobanja broj 1651/B sa iste nekropole. Ima koštani defekt lociran na istom mestu kao i prethodna, na povinuću leve parietalne kosti prema okcipitalnoj. Slabo je očuvana i pruža minimum antropoloških podataka koji su već navedeni. Međutim, karakter defekta se razlikuje na ovoj lobanji u odnosu na prethodnu. Dimenzije su samo neznatno veće; za oko $1 \mathrm{~cm}$, u svim pravcima. Vidimo da se radi o struganju konkretne zone, ali konstatujemo da "hirurg" nije dopro do spoljne moždane opne (Dura matris) primenom iste tehnike struganja kosti. Lamina interna nije probijena, dok lamina externa nedostaje, tj. dislocirana je struganjem. Sunđerasta koštana masa između ove dve površi pljosnate parietalne kosti ima reljefnu i nepravilnu osteoplastičnu reakciju. Vidno je da do zaceljenja defekta dolazi, ali ne ravnomerno i zato su formirane nepravilne konglomeracije novih osteoblasta. Da li se radi o pojavi i prisustvu prateće infekcije ili nečem drugom, nemoguće je decidno govoriti, ali je zato moguće postaviti direktnu dijagnozu započeta i prekinuta trepanacija. Takođe ostajemo bez odgovora na pitanje zašto je prekinut ovaj hirurški trepanacijski zahvat, ali je očigledno (prema stepenu bujanja mladih koštanih ćelija osteoblasta) da je smrt ove individue nastupila nekoliko meseci posle prekida ove i danas, osetljive hirurške operacije.

Na tabli III je ilustrovana lobanja broj 2570 sa nekropole Pećine. Tačniji izraz je lobanjski fragment, pošto je ova lobanja u celini sasvim loše očuvana. Kako pokazuje i pilot-skica na istoj tabli, vidimo da je jedan specifičan defekt kosti lociran na istom mestu kao i kod prethodne dve predmetne lobanje sa nekropole Više grobalja. To je povinuće leve parietalne kosti prema okcipitalnoj kosti. Oblik defekta nije više elipsast, nego je to kružna površina dimenzija oko $2 \mathrm{~cm}$. Razumljivo da je zbog procesa okoštavanja zid defekta konusan. Uz to, proces okoštavanja je bio toliko intenzivan, da je vremenom formirana jedna nova lamina interna, koja celom svojom površinom presvodi spoljnu moždanu opnu. I u ovom slučaju dijagnoza je sasvim jasna - uspešno obavljena trepanacija primenom cevaste bušilice sa dužim periodom preživljavanja. Taj period je iznosio svakako nekoliko godina i ne može biti direktan uzrok smrti ove individue koja je živela oko 45 godina.

Tabla IV prikazuje fotografski i radiološki snimak (u istoj projekciji) lobanje broj 2847 sa nekropole Pećine. Vidimo da se radi o defektu koji je lociran sa iste strane kao i u prethodna tri slučaja, s tim što je pomeren frontalno i zahvata i deo čeone kosti (za oko $1 \mathrm{~cm}$ prelazi sutura coronalis). Spoljne dimenzije ovog nepravilnog defekta su približno 4 x $6 \mathrm{~cm}$, dok su unutrašnje takođe nepravilne i iznose 2 × $3 \mathrm{~cm}$ (videti Rösnimak).

Analiza ovog koštanog defekta, po mišljenju autora, najverovatnije ide u dva pravca. Prvi je, da se radi o posebnom centru osifikacije na moždanom pokrivaču lobanje, i u tom slučaju je vrlo teško dati adekvatno tumačenje na antropološkom materijalu. Drugi pravac je trauma koja je nastala posle povređivanja / amputacije nekim oštrim predmetom. Pošto nije došlo do potpunog odvajanja koštane kapsule verovatno zbog prisustva mekih tkiva, došlo je do naknadne obliteracije delimično dislocirane stare i nove dodirne površine kosti. Kako pokazuje i Rö-snimak došlo je do srašćivanja po rubu defekta, tako da je funkcija koštanog dela moždanog pokrivača u potpunosti ostvarena. Ovaj slučaj samo na prvi pogled podseća na trepanaciju, odnosno više liči na vrlo redak tip povređivanja sa uspešnom sanacijom, koja svakako nije mogla biti direktan uzrok smrti ove individue sa antičkog Viminacijuma.

Naravno, i sve druge interpretacije koje nisu obuhvaćene ovim prilogom su moguće i dobrodošle. Zbog specifičnosti ovog defekta autor je izneo samo dva svoja mišljenja, bez pretenzija da pruži i konačnu dijagnozu.

Svedeno rečeno, u prilogu su posmatrane četiri lobanje sa tragovima trepanacionih hirurških zahvata sa uspešnim preživljavanjem "pacijenata" koje se kretalo od nekoliko meseci do nekoliko godina. Tipična trepanacija je vidna 
na tri lobanje, dok četvrta ima daleko složenije tumačenje koštanog defekta, za koje se ne može pouzdano reći da je i konačno.

$\mathrm{S}$ druge strane posmatrano, pomenute tri lobanje sa tipičnom trepanacijom imaju potpuno istu lokalizaciju (na levoj parietalnoj kosti). To ukazuje da se ne radi o povređivanju glave kao uzroku tih trepanacija, nego o nečemu drugom. Verovatno da progresivne glavobolje dolaze na mesto primarnih uzročnika.

Dalje posmatrano, nekropolu Više grobalja odlikuje tehnika struganja (lobanje broj 1037 i 1651/B), dok na nekropoli Pećine (lobanja 2570) srećemo tehniku direktnog bušenja. Svakako da su instrumenti za obe tehnike bili metalni, s tim što je strugač mogao imati i višestruku namenu. Međutim, bušilica / trepana je vrlo specifičan instrumenat i nije pronađen na Viminacijumu. Poznat je nalaz iz Bingena na Rajni, koji je datovan u II vek n.e. ${ }^{1} \mathrm{Na}$ slici 1 . ta trepana je grafički prikazana, uz takođe grafički model četiri osnovna tipa trepanacije lobanja. Ima centralnu vodilicu i nazupčenu kružnu ivicu, tako da je kružnim pomeranjem u levu i desnu stranu mogla da probuši koštani omotač i da bez problema stigne do spoljne moždane opne.

Opisana situacija otvara jedno novo pitanje.

Konstatovali smo dve tehnike trepaniranja na dve različite lokacije, odnosno nekropole Viminacijuma - Više grobalja i Pećine. Da li to znači i prisustvo dva različito obučena / školovana lekara u isto ili različito vreme na Viminacijumu? Odgovor će svakako dati kulturno-hronološki kontekst, ali on mora biti predmet prvenstveno arheološke analize!

\section{RESUME \\ Scull Trepanation in Ancient Viminacium - Anthropological Information}

Four sculls have been taken into consideration with traces of trepanatial chirurgical interventions when "patients" survived for several months up to several years. Typical trepanation could be observed on three sculls, while the fourth one possesses a much more complex osteological defect (which could not have been interpreted as definite).

On the other hand, the three sculls with typical trepanation mentioned above, show identical positioning at the left parietal bone (see tables I, II and III). That shows that one is not dealing with head injuries as causes for trepanation, but with something else. It is most likely, that heavy headaches can be considered as primary causes.

Further on, sculls found on the necropolis Više grobalja are characterized with grinding (sculls Nr. 1037 and 1651/B), while on the necropolis Pećine one is dealing with direct drilling (scull Nr. 2570). It is certain that the instruments used for both techniques were made of metal, taking into consideration that the instrument used for grinding could have served for several different purposes. However, the drilling tool - trepan, is a very specific instrument, which was not found at Viminacium. For example, one find is known from the Rhine limes (Bingen, see fig. 1).

Finally, this situation has opened a new question.

Two different trepanation techniques have been observed at two different locations, i.e. two Viminacium necropoles - Više grobalja and Pećine. Is it possible that two different medicians were practicing two different trepanation techniques at the same or at different times at Viminacium? The answer shall surely be given by culturalchronological context, which should be considered within a purely archaeological analysis.

1. Como 1925 


\section{BIBLIOGRAFIJA}

\section{Breitinger 1938}

Breitinger E. 1938. Zur Berechnung der Körperhöhe aus den langen Gliedmassenknocken, Anthrop. Anz. $14,249-274$.

\section{Como 1925}

Como J. 1925. Das Grab eines römischen Arztes in Bingen, Germania 3, 7-36.

\section{Farkas, Liptak 1971}

Farkas Gy., Liptak P. 1971. Antropološko istraživanje nekropole u Mokrinu, Dissertationes et Monographie, XI, Beograd, 239-271.

\section{Ferembach, Schwidetzky, Stloukal 1979}

Ferembach D., Schwidetzky I., Stloukal M. 1979. Empfehlungen für die Alters-und Geschlechtsdiagnose am Skelett, Homo XXX/2, 1-32.

\section{Karoly 1954}

Karoly L. 1954. Die vor-und frühgeschichtliche Trepanationen in Europa, Homo XV/1, 200-218.

\section{Korać 1986}

Korać M. 1986. Medicus et chirurgus ocularius iz Viminaciuima, Starinar 37, 53-71

\section{Mikić 1981}

Mikić Ž. 1981. Stanje i problemi fizičke antropologije u Jugoslaviji - praistorijski periodi, Centar za balkanološka ispitivanja ANU BiH, LIII/9, Sarajevo.

\section{Mikić 2000}

Mikić Ž. 2000. Antropološka saznanja o manastiru Davidovici, Mileševski zapisi 4, 17-28

\section{Sckroter 1957}

Sckroter E. 1957. Röntgenuntersuchungen an trepanierten Schädeln des Neolithikums, Forschritte der Röntgenstralen und der Nuklear-medizin 87, 538543.

\section{Ullrich, Weickmann 1964}

Ullrich H., Weickmann F. 1964 Prähistorische "Neurochirurgie" im mitteldeutschen Raum, Centralbraltt für Neurochirurgie, 24, 103-121. 

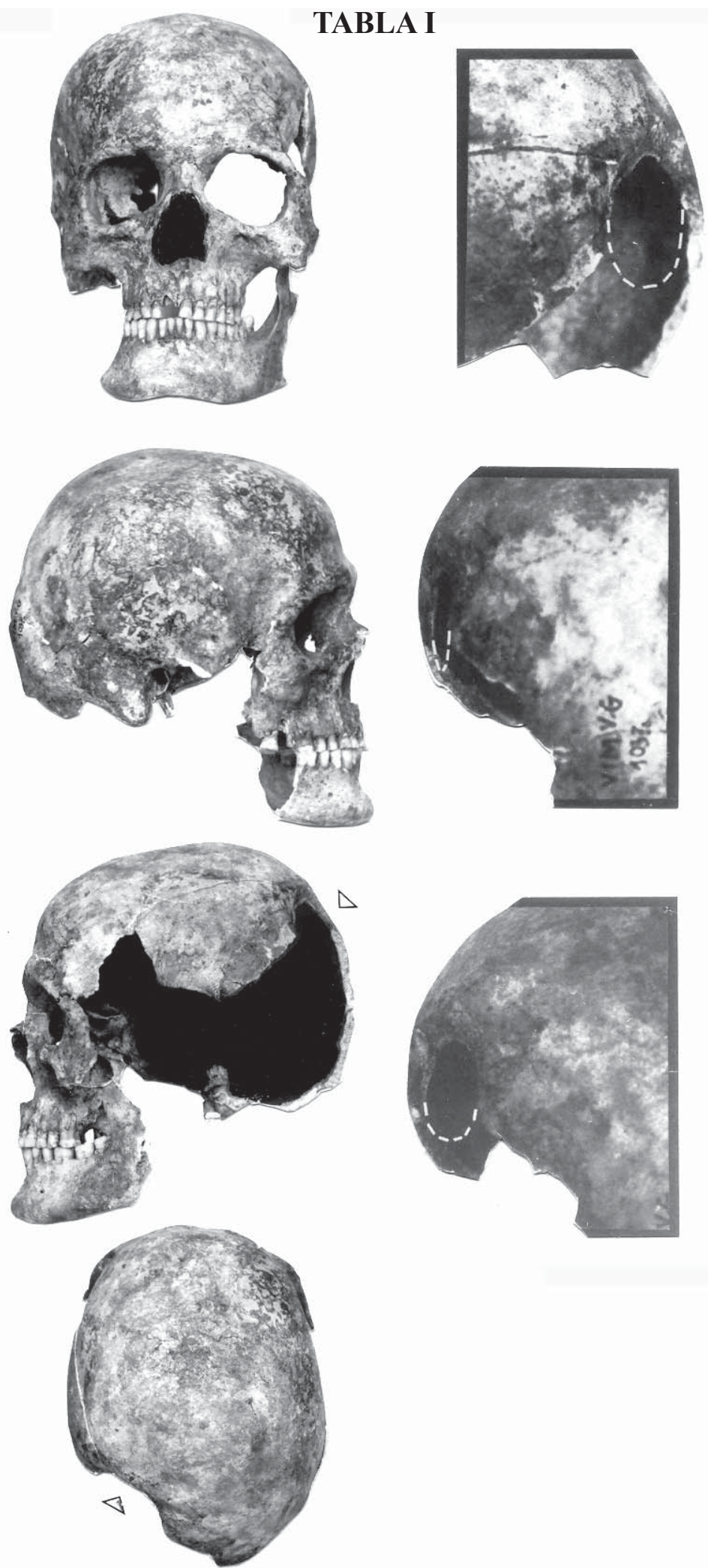

Antropološke projekcije lobanje sa nekropole Više grobalja broj 1037 (levo) uz detalje trepanacionog otvora na parietalnoj zoni 
TABLA II
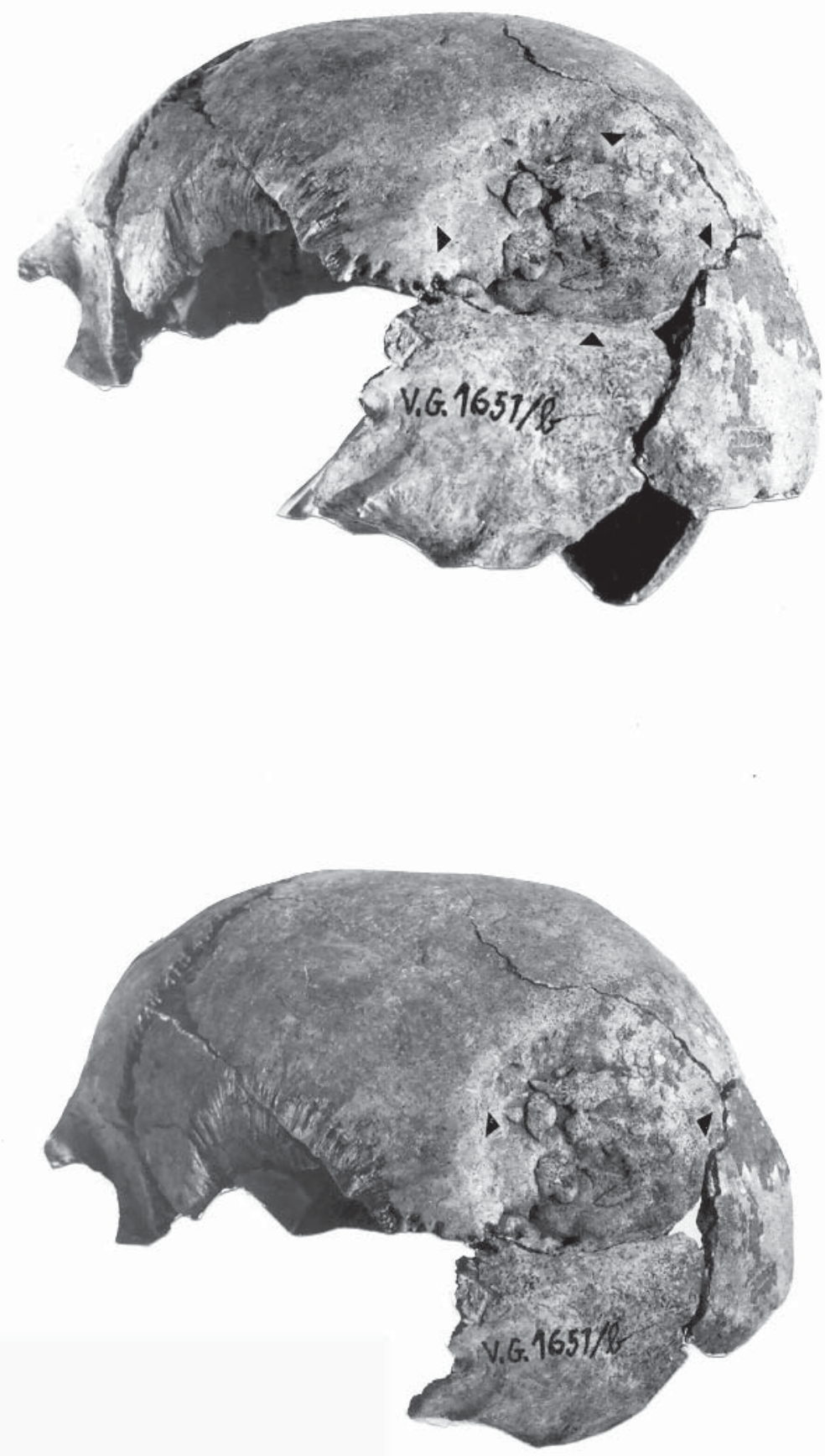

Lobanja sa nekropole Više grobalja broj 1651/B sa defektom na levoj okcipito-parietalnoj zoni 
TABLA III

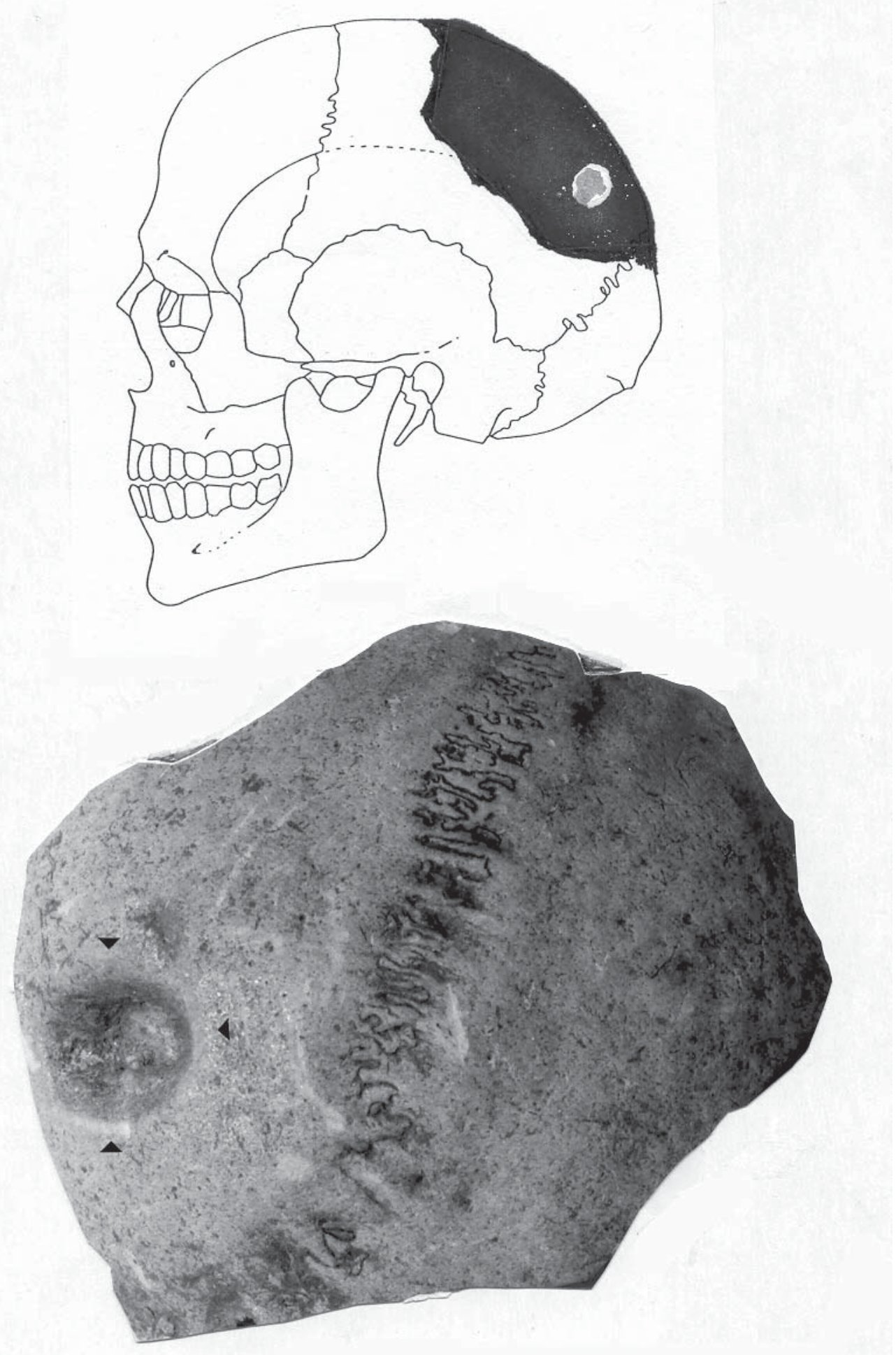

Fragment lobanje broj 2570 sa nekropole Pećine (u prirodnoj veličini), sa lokalizacijom trepanacionog otvora na pilot-skici 


\section{TABLA IV}
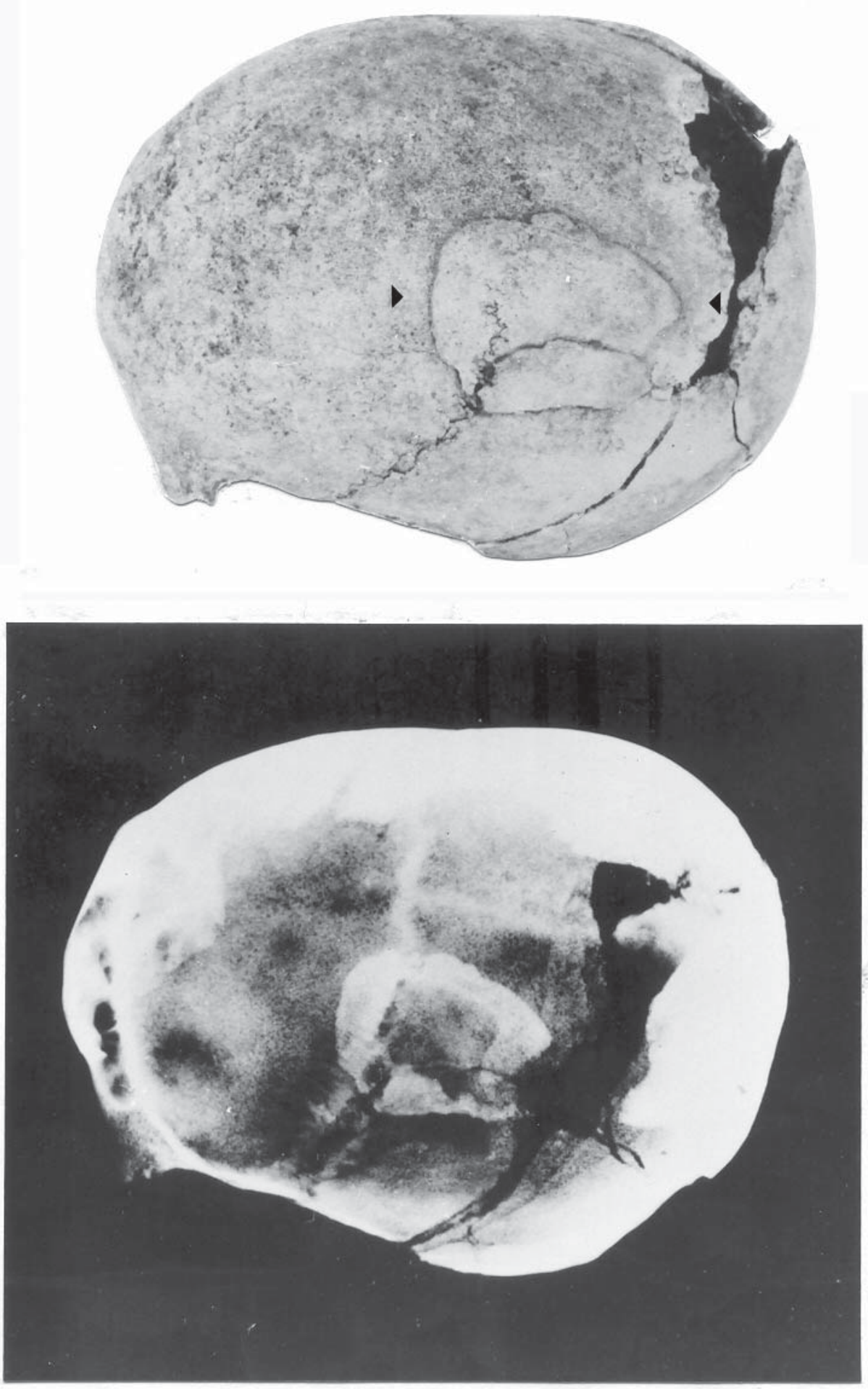

Gore: Lobanja sa nekropole Pećine broj 2847 sa uočenim defektom

Dole: Rentgenski snimak lobanje i defekta 

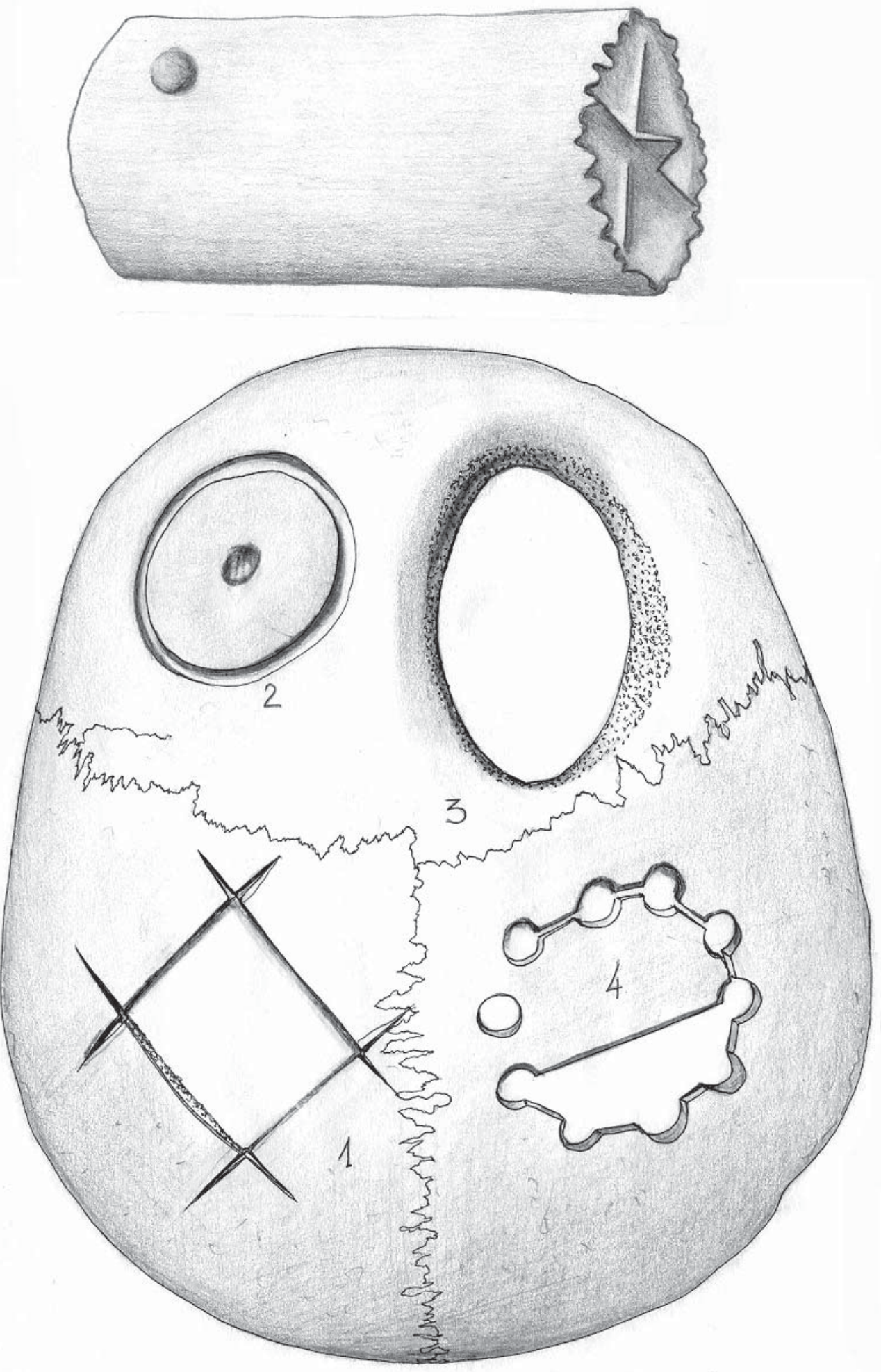

Slika 1. Gore: Metalna trepana iz Bingena na Rajni (prema J. Como 1925)

Dole: Grafički model četiri osnovna tipa trepanacije: 1 . testerisanje, 2. direktno bušenje, 3. struganje, 4 . višestruko bušenje 


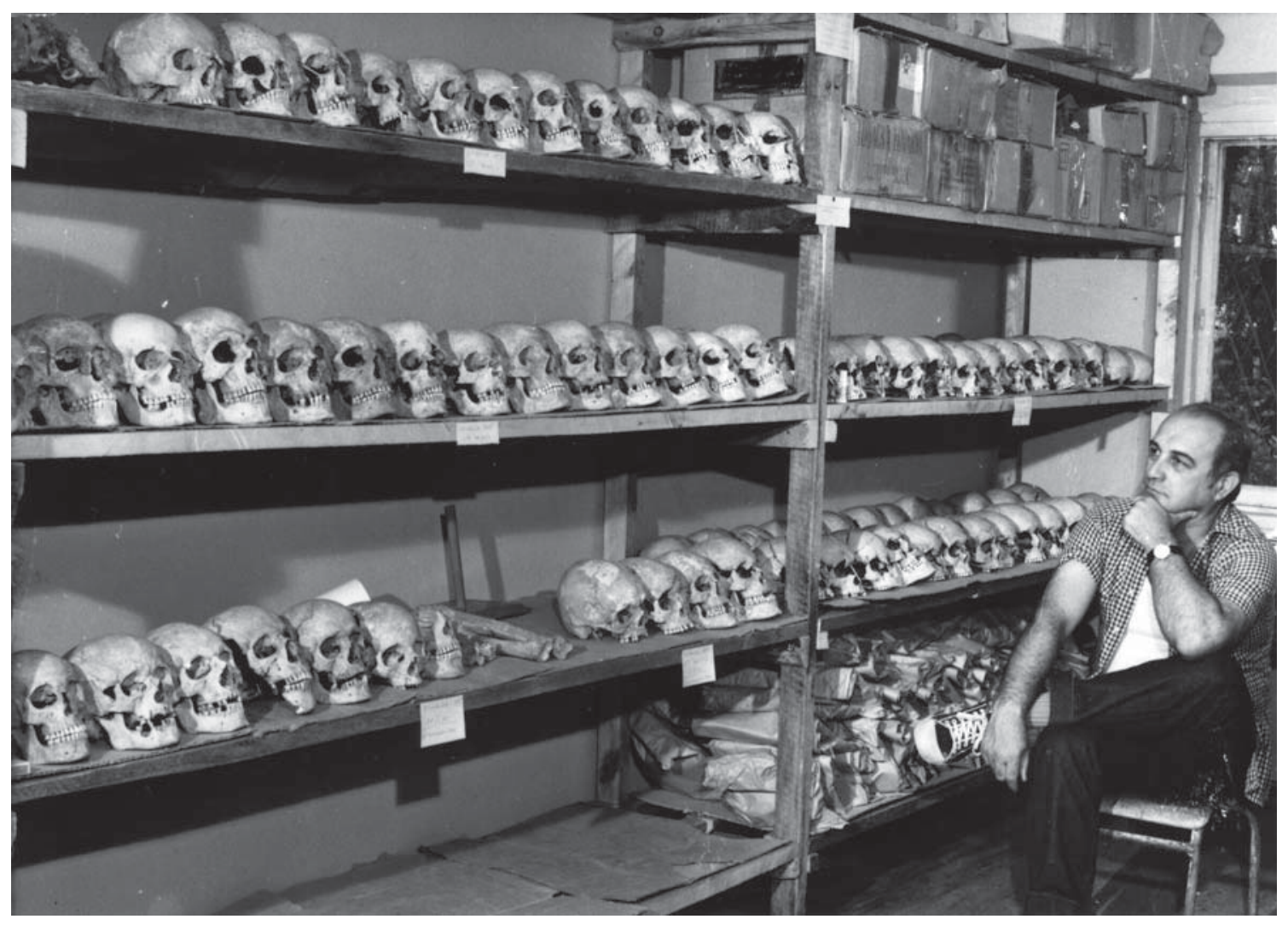

Deo antropološke zbirke Viminacium (snimak oko 1980. godine) 